\title{
STUDI PEMBUATAN KECAP ASIN DARI AMPAS TAHU DENGAN KOSENTRASI GARAM YANG BERBEDA
}

\author{
(Study of Salty Soy Sauce Production Made from Tofu Pulps with Different Salt \\ Concentrations)
}

\author{
Teuku Rushariandi ${ }^{1}$, Ryan Moulana $^{1}$, Murna Muzaifa ${ }^{1 *}$ \\ ${ }^{1}$ Program Studi Teknologi Hasil Pertanian, Fakultas Pertanian, Universitas Syiah Kuala
}

\begin{abstract}
Abstrak. Penelitian ini bertujuan untuk mengetahui pengaruh konsentrasi garam terhadap mutu dari kecap asin ampas tahu. Penelitian ini menggunakan Rancangan Acak Lengkap (RAL) Non Faktorial, dengan faktor konsentrasi garam $(\mathrm{G})$ yang terdiri atas 4 perlakuan yaitu G1 $=10 \%, \mathrm{G} 2=15 \%, \mathrm{G} 3=20 \%$ dan $\mathrm{G} 4=25 \%$. Ulangan dilakukan sebanyak 4 kali sehingga dihasilkan 16 satuan percobaan. Analisa yang dilakukan pada produk kecap asin ampas tahu ini meliputi analisis fisikokima dan analisis organoleptik. Analisis fisikokimia meliputi analisis kadar air, analisis protein, analisis kadar lemak, analisis kadar abu, analisis kekentalan. Analisis organoleptik yaitu uji hedonik yang meliputi analisis warna, rasa dan aroma. Hasil penelitian menunjukkan bahwa ampas tahu memiliki kandungan yaitu air $83,59 \% \pm 2,18 \%$, protein $5,37 \% \pm 0,40 \%$, lemak $2,27 \% \pm$ $0,72 \%$, dan abu $2,19 \% \pm 0,72 \%$. Konsentrasi garam berpengaruh sangat nyata terhadap hedonik warna, aroma, rasa, dan viskositas, berpengaruh nyata terhadap kadar air dan protein terlarut serta berpengaruh tidak nyata terhadap kadar abu kecap asin ampas tahu yang dihasilkan. Kecap asin ampas tahu yang dihasilkan memiliki tingkat kesukaan warna, aroma dan rasa yang berbeda, dengan kisaran dari tidak suka sampai netral. Berdasarkan uji hedonik, produk terbaik diperoleh pada perlakuan konsentrasi garam $20 \%$ dengan kadar air $14.19 \%$, protein terlarut $3,87 \%$, kadar abu $5.23 \%$ dan viskositas yaitu $3.88 \%$.
\end{abstract}

Kata Kunci: ampas tahu, garam, kecap.

\begin{abstract}
This study was aimed to determine the effect of salt concentration on the quality of salty tofu pulps soy sauce. This study used a completely randomized design (CRD) non factorial with a salt concentration factor (G) consisting of 4 treatments which were G1 $=10 \%, \mathrm{G} 2=15 \%, \mathrm{G} 3=20 \%$ and $\mathrm{G} 4=25 \%$. This study was repeated 4 times so 16 experimental units was produced. Analysis performed on the salty soy sauce included physicochemical analysis and organoleptic analysis. The physicochemical analysis consisted of water content, protein content, fat content, ash content, and viscosity analysis. Organoleptic analysis which is hedonic test consisted of the analysis of color, taste and aroma. The results showed that the salty tofu pulps soy sauce had a water content $(83.59 \% \pm 2.18 \%)$, protein content $(5.37 \% \pm 0.40 \%)$, fat content $(2.27 \% \pm 0.72 \%)$ and ash content $(2,19 \% \pm 0,72 \%)$. Salt concentrations affected very significantly on the hedonic (color, taste, and aroma) and viscosity, affected significantly on the water content and soluble protein content, and had no effect on the ash content of the product. The salty soy sauce produced different preference level of color, taste and aroma ranging from dislike to neutral. Based on the hedonic test, the best product was obtained in $20 \%$ of salt concentration treatments having the water content (14.19\%), soluble protein (3.87\%), ash content (5.23\%) and viscosity $(3.88 \%)$.
\end{abstract}

Keywords: tofu pulps, salt, soy sauce.

\section{PENDAHULUAN}

Potensi ampas tahu yang memiliki sumber protein dapat dijadikan alternatif bahan baku utama pada pembuatan kecap yang tidak membutuhkan biaya besar. Selama ini kecap dibuat dengan bahan baku kedelai. Maka ampas tahu ini dapat dimanfaatkan sebagai bahan utama pembuatan kecap ampas tahu. Diketahui dari komposisi kimianya, ampas tahu 
memiliki kandungan protein 5,2\% lemak 3,79\%, air 51,63\% dan abu 1,21\%, maka potensi ampas tahu dapat di-olah menjadi banyak jenis olahan pangan (Rahman, 2011).

Kecap merupakan sumber protein yang baik karena kandungan asam amino yang tinggi. Dengan perlakuan fermentasi pada kecap, kandungan gizi dalam kecap akan lebih mudah dicerna oleh tubuh (Astawan, 2004). Proses pembuatan kecap terdiri dari dua tahapan fermentasi, yaitu fermentasi padat dan fermentasi cair. Proses fermentasi padat atau biasa disebut dengan istilah koji merupakan fermentasi dengan menggunakan starter (kapang) yang dilakukan selama dua sampai empat hari, sedangkan proses fermentasi cair atau moromi adalah campuran antara koji dan larutan garam dengan konsentrasi larutan garam tertentu (Haryoto, 2000).

Kecap pada umumnya diolah dengan bahan baku kedelai utuh. Bahan baku yang menjadi alternatif dalam proses pembuatan kecap yaitu, ampas tahu. Khas dari kecap umumnya adalah bewarna coklat tua, berbau khas kecap rasa asin yang dapat mempengaruhi rasa pada masakan (Silvia, 2011).

Pada umumnya pembuatan kecap di Indonesia dilakukan dengan metode fermentasi (Kusumo dalam Sukaton,1994). Pembuatan Kecap terdiri dari dua cara yaitu dengan metode fermentasi kapang (Solid Stage Fermentation) dan fermentasi kedua dengan larutan garam (brine fermentation). Pada tahap proses fermentasi kapang terjadi perubahan senyawa komplek yaitu karbohidrat menjadi bentuk yang lebih sederhana. Sedangkan larutan garam akan menimbulkan keluarnya molekul molekul protein yang larut air. Akibat adanya Aktivitas bakteri dan khamir pada fermentasi ini akan menghasilkan flavour pada kecap dan mempengaruhi mutu yang dihasilkan (Kuswara, 1992).

\section{METODE PENELITIAN}

\section{Bahan dan Alat}

Bahan pembuatan kecap yaitu ampas tahu dari industri rumah tahu pak Sugeng di Kecamatan Blower tepi kali, Laru tempe, garam, air, tepung tapioka dan gula aren 50 gram untuk 1 sampel, dan bumbu tambahan (rempah). Bahan yang digunakan untuk analisis adalah yaitu $\mathrm{H}_{2} \mathrm{SO}_{4}, \mathrm{H}_{3} \mathrm{BO}_{3} 4 \%$, NaOH $40 \%$, Metilen Red, Metilen Blue.

Peralatan yang digunakan pada penelitian ini adalah panci, sendok pengaduk, ember, kain saring, tampah, dandang, botol dan penutup botol. Sedangkan alat yang digunakan pada analisis adalah oven, cawan, Brookfield viscometer, timbangan analitik, cawan porselin, labu 25 ml, labu Kjeldahl, destilasi, destruksi, gelas kimia, desikator, dan tanur.

\section{Rancangan Penelitian}

Penelitian ini menggunakan Rancangan Acak Lengkap (RAL) Non Faktorial dengan faktor perlakuan garam pada konsentrasi. Konsentrasi garam terdiri atas 4 perlakuan dan diperoleh 4 ulangan sehingga menghasilkan 16 satuan percobaan.

\section{Analisis Data}

Bahan baku dilakukan dengan analisis proksimat yaitu meliputi kadar air, protein, lemak, karbohidrat, dan abu. Adapun analisa yang dilakukan pada produk kecap ampas tahu ini meliputi analisis fisikokima dan analisis organoleptik. Analisis fisikokimia yaitu meliputi analisis kadar air, analisis protein, analisis kadar abu dan analisis kekentalan. Analisis organoleptik yaitu uji hedonik yang meliputi analisis warna, rasa dan aroma. 


\section{HASIL DAN PEMBAHASAN}

\section{Analisis Bahan Baku (Ampas Tahu)}

Pada penelitian ini, nilai proksimat dari ampas tahu dihitung untuk mengetahui kandungan gizi ampas tahu sebelum diolah menjadi kecap. Hasil analisis proksimat untuk ampas tahu dapat dilihat pada Tabel dibawah ini.

Tabel 1. Nilai proksimat ampas tahu.

\begin{tabular}{cc}
\hline Kandungan Gizi & Nilai \pm Standard Deviasi \\
\hline Air & $83,59 \pm 2,18$ \\
Protein & $5,37 \pm 0,40$ \\
Lemak & $2,27 \pm 0,31$ \\
Abu & $2,19 \pm 0,01$ \\
\hline
\end{tabular}

Kadar air pada ampas tahu diperoleh sebesar 83,59\% $\pm 2,18 \%$. Nilai kadar air ini lebih rendah dibandingkan Sulistiani (2004), dimana kadar air ampas tahu 89,88\%. Adapun menurut Arbaiyah (2003), mengatakan bahwa kadar air pada ampas tahu yaitu 84,1\%. Kadar protein pada ampas tahu yaitu 5,37\% $\pm 0,40 \%$. Protein pada ampas tahu ini berbeda lebih rendah dibandingkan hasil analisis protein ampas tahu. menurut Arbaiyah (2003), yaitu 5,6\% dan lebih tinggi dibandingkan protein ampas tahu menurut Sulistiani (2004). Kadar lemak pada ampas tahu diperoleh sebesar 2,27\% $\pm 0,72 \%$. Nilai kadar lemak ini tidak berbeda jauh dibandingkan hasil analisis ampas tahu oleh Fridata (2014) dan Manurung (2016), dengan nilai masing masing 2,1\% dan 2,2\%. Kadar abu pada ampas tahu diperoleh sebesar 2,19\% \pm 0,72\%. Nilai kadar abu ini jauh lebih tinggi dibandingkan Fridata (2014), yaitu 0,32\%.

\section{Analisis Fisikokimia}

\section{Analisis Kadar Air}

Hasil analisis diperoleh bahwa kadar air kecap yang dihasilkan berkisar dari 40,60\%$52,76 \%$, dengan rata-rata umum 46,99\%. Kadar air kecap jauh lebih kecil dibandingkan kadar air ampas tahu sebagai bahan baku utama. Hal ini dikarenakan adanya penambahan kadar garam yang menyebabkan air pada ampas tahu terikat. Pengaruh konsentrasi garam terhadap kadar air dari kecap dapat dilihat pada Gambar 1.

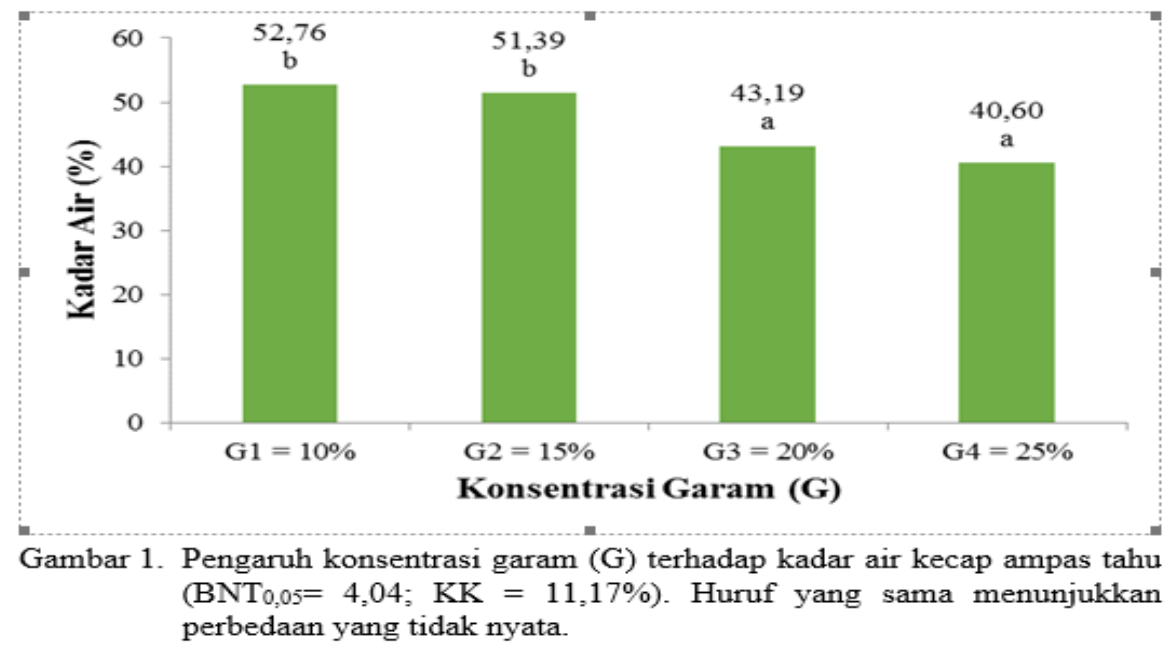


Dari Gambar 1 dapat dilihat bahwa kadar air tertinggi terdapat pada perlakuan konsentrasi garam $10 \%(\mathrm{G} 1)$, dengan nilai 52,76\%. Kadar air ini berbeda tidak nyata dengan perlakuan konsentrasi garam 15\% (G2), dimana nilainya 51,39\%. Akan tetapi, nilai ini berbeda nyata terhadap perlakuan konsentrasi garam 20\% (G3) dan 25\% (G4). Adapun kadar air yang paling rendah terdapat pada perlakuan konsentrasi garam 25\% (G4), yang berbeda tidak nyata dengan perlakuan konsentrasi garam 20\% (G3).

Gambar 1 juga menunjukkan bahwa peningkatan konsentrasi garam menyebabkan penurunan kadar air kecap. Hal ini dikarenakan garam bersifat mengikat air. Penambahan garam yang lebih banyak akan menyebabkan air yang diikat oleh garam menjadi semakin banyak. Hal ini diperkuat dengan penelitian Rochima (2005) yang mengkaji fermentasi garam dalam pembuatan salah satu jenis ikan asin. Rochima (2005) mengatakan bahwa konsentrasi garam yang lebih tinggi menghasikan kadar air yang lebih rendah karena volume air yang diserap dan diikat oleh garam juga semakin banyak.

\section{Analisis Kadar Protein Terlarut}

Hasil analisis diperoleh bahwa kadar protein terlarut kecap yang dihasilkan berkisar dari 3,11\%-4,47\%, dengan rata-rata umum 3,82\%. Bila dibandingkan dengan kandungan protein bahan baku, kadar proteinnya yaitu 5,37\%. Ini berarti sebagian besar protein diubah oleh mikroba menjadi protein terlarut. konsentrasi garam berpengaruh terhadap kadar protein terlarut kecap. Pengaruh konsentrasi garam terhadap protein terlarut dari kecap dapat dilihat pada Gambar 2.

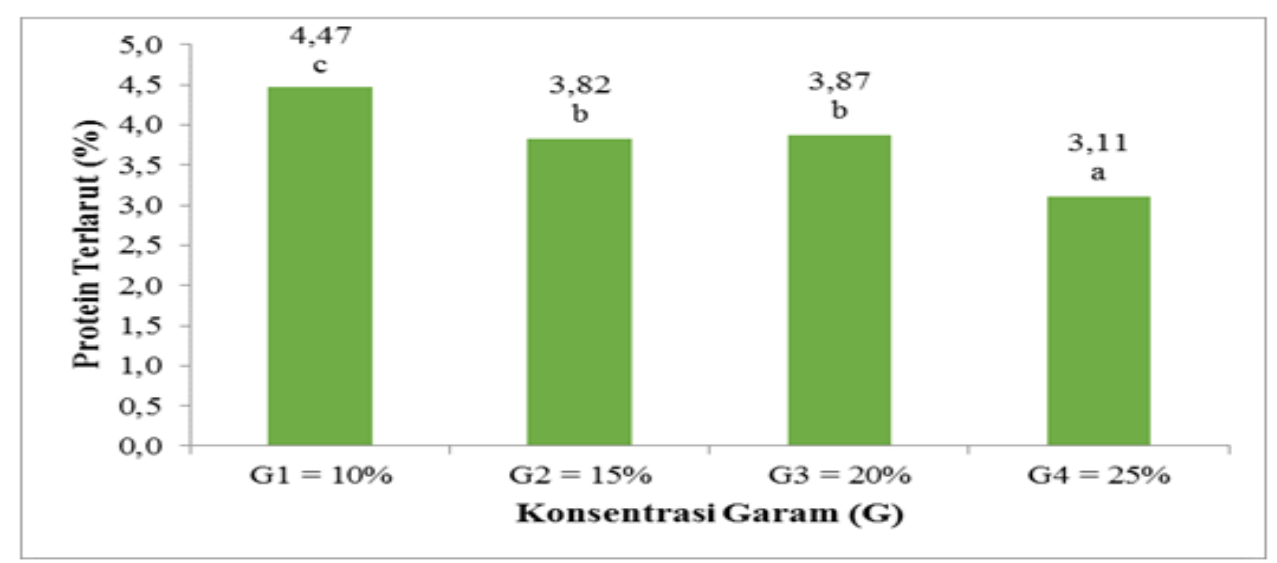

Gambar 2. Pengaruh konsentrasi garam (G) terhadap kadar air kecap ampas tahu $\left(\mathrm{BNT}_{0,05}=0,35 ; \mathrm{KK}=11,98 \%\right.$ ). Huruf yang sama menunjukkan perbedaan yang tidak nyata.

Dapat dilihat bahwa kadar protein tertinggi terdapat pada perlakuan konsentrasi garam 10\% (G1), dengan nilai 4,47\%. Kadar protein terlarut ini berbeda nyata dengan semua perlakuan lainnya. Adapun kadar protein terlarut yang paling rendah terdapat pada perlakuan konsentrasi garam 25\% (G4). Pada penelitian Astuti dan Wardani (2016), kadar protein terlarut dari kecap ampas tahu yang digunakan berkisar dari 2,37\%-6,83\%. Ini menunjukkan bahwa kadar protein keduanya tidak jauh berbeda. Pada analisis kadar protein terlarut kecap, penambahan garam juga mengakibatkan penurunan kadar protein terlarutnya. Meskipun pada konsentrasi $15 \%$ dan $20 \%$ terjadi peningkatan nilai grafik, keduanya menunjukkan perbedaan yang tidak nyata. Penurunan kadar protein terlarut ini diduga karena penambahan garam yang lebih banyak menghambat kerja enzim pemecah protein meskipun mikrobanya tahan terhadap konsentrasi garam yang lebih tinggi. Kumalaningsih dan Hidayat (1995), mengatakan bahwa 
peran kapang dalam fermentasi kecap sangat penting karena kapang menghasilkan enzim yang memecah substrat menjadi senyawa-senyawa terlarut. Salah satu enzim pada fermentasi kecap adalah enzim protease yang memecah substrat protein menjadi protein terlarut dan asam amino.

\section{Analisis Kadar Abu}

Hasil analisis diperoleh bahwa kadar abu kecap yang dihasilkan berkisar dari 4,43\%$5,23 \%$, dengan rata-rata umum 4,96\%. Analisis ragam menunjukkan bahwa konsentrasi garam $(\mathrm{G})$ berpengaruh tidak nyata $(\mathrm{P}>0,05)$ terhadap kadar abu kecap. Hasil analisis kadar abu kecap dapat dilihat pada Tabel 2.

Tabel 2. Kadar abu kecap asin ampas tahu.

\begin{tabular}{cc}
\hline Konsentrasi Garam & Kadar Abu (\%) \\
\hline G1 $=10 \%$ & 4,43 \\
G2 $=15 \%$ & 4,97 \\
G3 $=20 \%$ & 5,23 \\
G4 $=25 \%$ & 5,21 \\
\hline
\end{tabular}

Meskipun berpengaruh tidak nyata, dapat dilihat bahwa kadar abu pada kecap ampas tahu meningkat dengan semakin meningkatnya konsentrasi garam (hingga ke konsentrasi $20 \%$, lalu sedikit menurun pada konsentrasi 25\%). Kadar abu pada kecap juga mengalamipeningkatan dibandingkan kadar abu pada ampas tahu. Ini dikarenakan pada pembuatan kecap ditambahkan bahan-bahan lain (garam dan rempah-rempah) yang juga memiliki kandungan abu.

\section{Analisis Kekentalan (Viskositas)}

Dari hasil analisis diperoleh bahwa viskositas kecap yang dihasilkan berkisar dari 2,384,00 Poise dengan rata-rata umum 3,28 Poise. Analisis ragam menunjukkan bahwa konsentrasi garam berpengaruh terhadap viskositas kecap. Pengaruh konsentrasi garam terhadap viskositas kecap dapat dilihat pada Gambar 3 yang menunjukkan bahwa viskositas kecap tertinggi diperoleh pada perlakuan konsentrasi garam $25 \%(\mathrm{G} 4)$ dengan nilai 4,0 Poise, yang berbeda tidak nyata dengan perlakuan konsentrasi garam $20 \%$ (G3), dimana nilainya 3,88 Poise. Akan tetapi, kedua perlakuan ini berbeda nyata dengan perlakuan konsentrasi garam 10\% (G1) dan 15\% (G2), dengan nilai masing-masing 2,38 Poise dan 2,88 Poise.

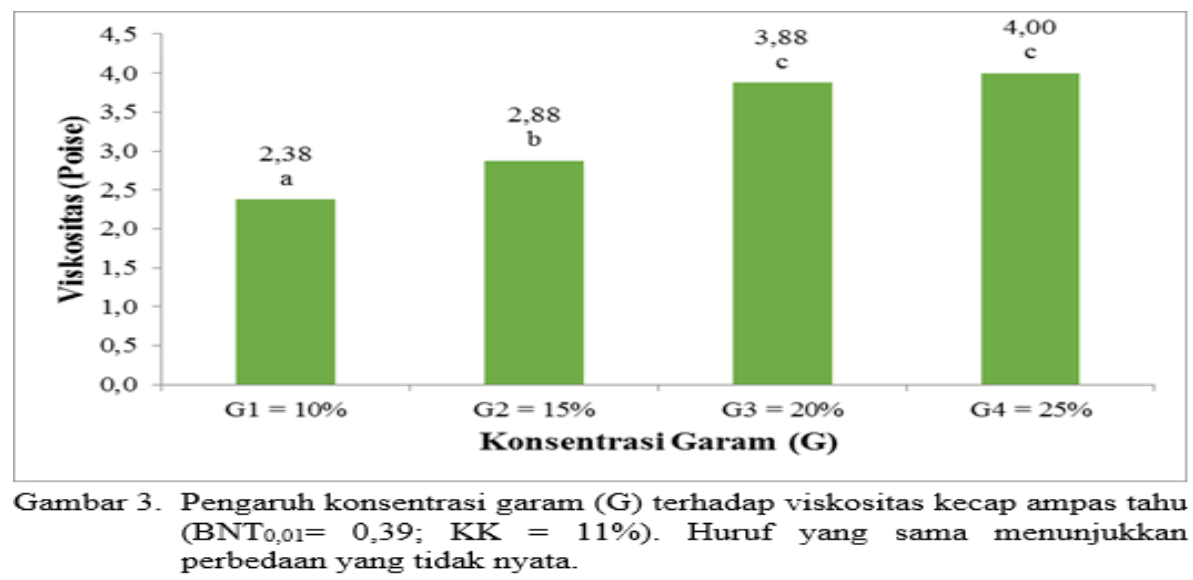


Gambar 3 juga menunjukkan bahwa viskositas kecap meningkat dengan bertambahnya konsentrasi garam. Hal ini dikarenakan garam memiliki kemampuan mengikat air sehingga air dalam bahan baku diserap dan diikat oleh garam. Semakin banyak air yang diikat, maka cairan akan semakin mengental. Hal ini diperkuat oleh Chernanda (2011) yang mengatakan bahwa garam bersifat higroskopis sehingga akan menyerap kandungan air dalam bahan.

\section{Uji Organoleptik \\ Uji Hedonik Warna}

Hasil uji organoleptik diperoleh bahwa tingkat kesukaan panelis terhadap warna kecap yang dihasilkan berkisar dari 2,25 (tidak suka) - 3,34 (netral), dengan rata-rata umum 2,78 (netral). Analisis ragam menunjukkan bahwa konsentrasi garam $(\mathrm{G})$ berpengaruh sangat nyata $(\mathrm{P} \leq 0,01)$. Pengaruh konsentrasi garam terhadap hedonik warna dari kecap dapat dilihat pada Gambar 4.

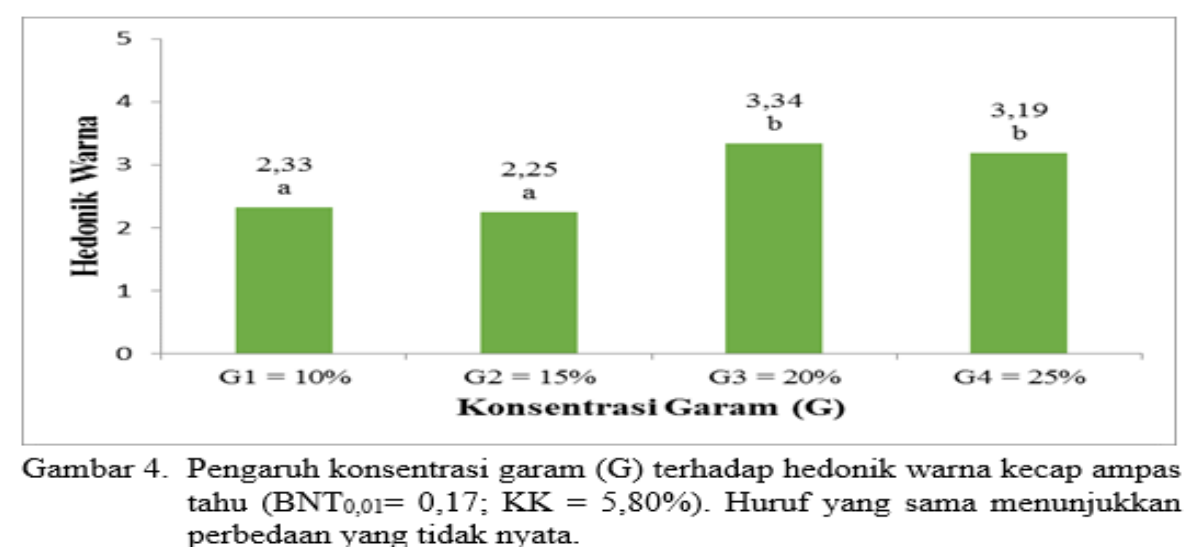

Gambar 4 juga menunjukkan bahwa konsentrasi garam yang lebih tinggi menghasilkan warna yang lebih disukai panelis. Hal ini diduga karena penambahan garam yang lebih tinggi dapat menghambat pertumbuhan lainnya yang dapat menyebabkan timbulnya aroma yang tidak diinginkan. Desniar, dkk (2009) mengatakan bahwa garam bersifat selektif dalam proses fermentasi. Garam dapat menghambat pertumbuhan mikroba penyebab kebusukan sehingga hanya mikroba yang tahan garam yang dapat bertahan hidup.

\section{Uji Hedonik Aroma}

Hasil uji organoleptik diperoleh bahwa tingkat kesukaan panelis terhadap aroma kecap yang dihasilkan berkisar dari 2,19 (tidak suka) - 2,88 (netral), dengan rata-rata umum 2,50 (netral) . Analisis ragam menunjukkan bahwa konsentrasi garam $(\mathrm{G})$ berpengaruh sangat nyata $(\mathrm{P} \leq 0,01)$. Pengaruh konsentrasi garam terhadap hedonik warna dari kecap dapat dilihat pada Gambar 5.

Gambar 5 menunjukkan bahwa tingkat kesukaan panelis terhadap aroma yang paling tinggi terdapat pada perlakuan konsentrasi garam 20\% (G3), dengan nilai 2,88 (netral). Hasil ini berbeda tidak nyata terhadap perlakuan konsentrasi garam 25\%, dengan nilai 2,74 (netral). Adapun tingkat kesukaan panelis yang paling rendah terdapat pada perlakuan konsentrasi garam 10\% (G1) dan 15\% (G2), dengan nilai 2,19 dan 2,20 (netral). Pada penelitian Hidayah (2014), panelis juga menyukai aroma kecap asin koro benguk pada konsentrasi $20 \%$ dan $23 \%$. Penambahan konsentrasi garam juga meningkatkan kesukaan panelis terhadap aroma kecap yang dihasilkan. Hal ini dikarenakan peran garam yang dapat menghilangkan bau langu dan 
dapat menghambat pertumbuhan mikroba pembusuk. Menurut Aoyagi (1984) Penyebab timbulnya bau langu adalah enzim lipoksigenase yang menguraikan lemak kedelai sebagai penghasil senyawa penyebab bau langu. Oktavia (2012) mengatakan bahwa garam dapat menghilangkan bau langu khas kedelai pada berbagai pengolahan produk, misalnya tempe.

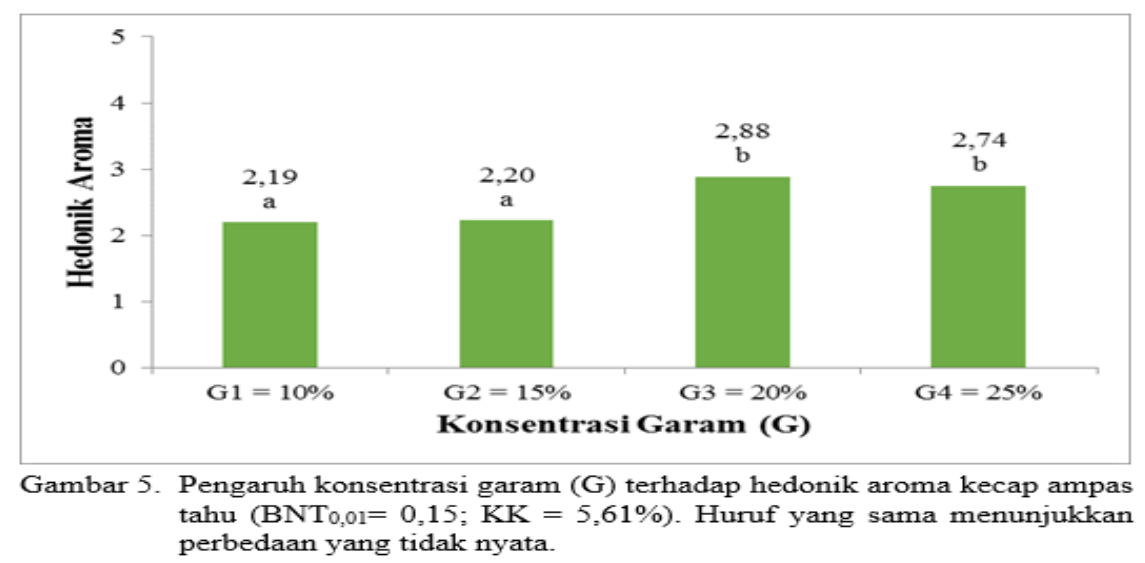

\section{Uji Hedonik Rasa}

Dari hasil uji organoleptik diperoleh bahwa tingkat kesukaan panelis terhadap rasa kecap yang dihasilkan berkisar dari 2,06 (tidak suka) - 2,89 (netral), dengan rata-rata umum 2,43 (tidak suka). Analisis ragam menunjukkan bahwa konsentrasi garam (G) berpengaruh sangat nyata $(\mathrm{P} \leq 0,01$ Pengaruh). konsentrasi garam terhadap hedonik rasa dari kecap dapat dilihat pada Gambar 6.

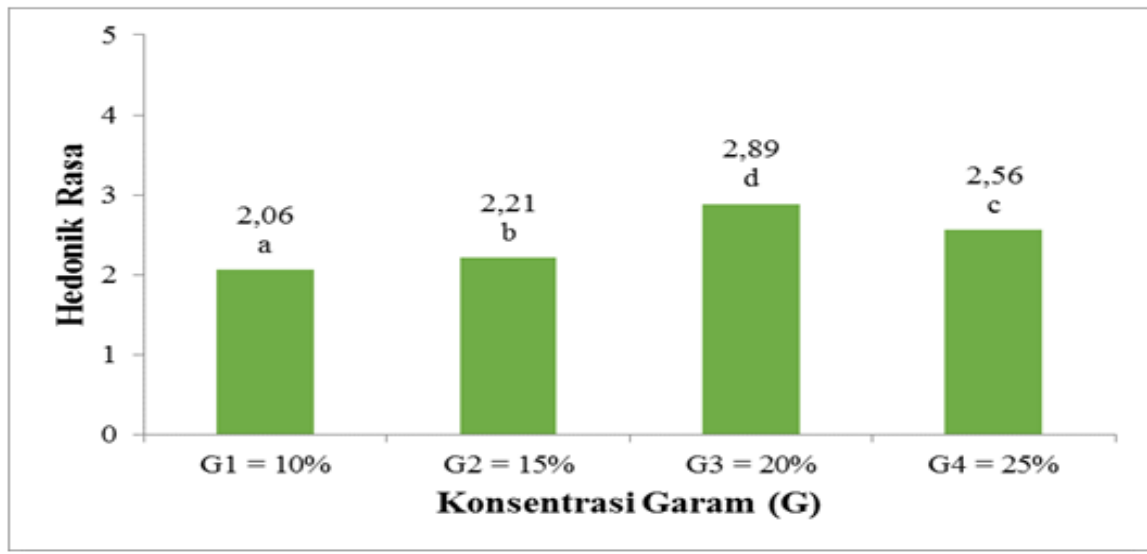

Gambar 6. Pengaruh konsentrasi garam (G) terhadap hedonik aroma kecap ampas tahu $\left(\mathrm{BNT}_{0,01}=0,15 ; \mathrm{KK}=5,60 \%\right)$.

Dari Gambar 6 dapat dilihat bahwa tingkat kesukaan panelis tertinggi terdapat pada perlakuan konsentrasi garam 20\% (G3), dengan nilai 2,89 (netral). Nilai ini berbeda nyata terhadap semua perlakuan lainnya. Adapun tingkat kesukaan panelis yang paling rendah terdapat pada perlakuan konsentrasi garam 10\% (G2), dengan nilai 2,06 (tidak suka). Penambahan konsentrasi garam yang lebih tinggi (hingga ke konsentrasi 20\%) menyebabkan panelis lebih menyukai rasa kecap yang dihasilkan. Hal ini dikarenakan proses fermentasi lebih optimal pada konsentrasi garam yang lebih tinggi. Konsentrasi garam yang lebih tinggi dapat menghambat pertumbuhan mikroba pembusuk (Desniar dkk., 2009). Akan tetapi, pada 
konsentrasi garam 25\%, tingkat kesukaan panelis mulai menurun. Ini dikarenakan garam pada konsentrasi $25 \%$ menyebabkan rasa kecap sangat asin. Oleh karena itu, panelis menjadi kurang suka.

\section{Kesimpulan}

\section{KESIMPULAN DAN SARAN}

1. Ampas tahu memiliki kandungan yaitu air $83,59 \% \pm 2,18 \%$, protein $5,37 \% \pm 0,40 \%$, lemak $2,27 \% \pm 0,72 \%$, karbohidrat $6,58 \% \pm 2,72 \%$ dan abu $2,19 \% \pm 0,72 \%$.

2. Konsentrasi garam dapat berpengaruh terhadap sifat fisikokimia kecap, dimana semakin tinggi konsentrasi garam, protein terlarut dan kadar air kecap semakin menurun jumlahnya, sedangkan pada viskositasnya dapat meningkat.

3. Kecap ampas tahu yang dihasilkan memiliki tingkat kesukaan warna, aroma dan rasa yang berbeda, dengan kisaran dari tidak suka sampai netral.

4. Berdasarkan uji organoleptik, produk terbaik diperoleh pada perlakuan konsentrasi garam $20 \%$ dengan kadar air $14.19 \%$, protein terlarut $3,87 \%$, kadar bu $5.23 \%$ dan viskositas yaitu $3.88 \%$.

\section{Saran}

Perlu dilakukan fermentasi moromi yaitu campuran tempe gembus dikombiasi dengan kedelai murni dan larutan garam dilakukan dengan prosedur skala pabrik yang lebih tepat agar mendapatkan kualitas cairan kecap yang lebih baik.

\section{DAFTAR PUSTAKA}

Arbaiyah, ita. 2003. Kandungan Protein dan Kalsium serta Daya Terima Susu Kedelai yang dibuat dari Ampas Tahu dengan Penambahan Bahan Pengental. Skripsi. Fakultas Kesehatan USU. Medan.

Aoyagi, A. dan Shurtleff, W. 1984. Tofu and Soymilk Production, Second Edition, The Book Of Tofu, A Craft Technical Manual, Second Edition, Soyfoods Center. Lafayette. California.

Astuti, A.F. dan A.K. Wardani. 2015. Pengaruh Lama Fermentasi Kecap Ampas Tahu terhadap Kualitas Fisik, Kimia dan Organoleptik. Jurnal Pangan dan Agroindustri Vol. 4 No 1 Hal. 72-83.

Astawan, M. 2004. Teknologi Pengolahan Pangan Nabati. Penerbit Akamedika Presindo. Jakarta.

Chernanda. R dan Hadi, R.M.E. 2011. Pemanfaatan Limbah Ampas Tahu sebagai Bahan Baku Proses Produksi Kerupuk Pengganti Tepung Tapioka. Prosiding SnaPP2011 Sains, Teknologi dan Kesehatan Vol. 2 No.1 Hal. 173-180.

Desniar, D. Poernomo dan W. Wijatur. 2009. Pengaruh Konsentrasi Garam pada Peda Ikan Kembung (Rastrelliger sp.) dengan Fermentasi Spontan. Jurnal Pengolahan Hasil Perikanan Indonesia Vol.12 No. 1 Hal. 73-87. 
Fridata, I.G. 2014. Kualitas Biskuit Keras dengan Kombinasi Tepung Ampas Tahu dan Bekatul Beras Merah. Skripsi. Universitas Atmajaya Yogyakarta, Yogyakarta.

Haryoto. 2000. Teknologi Tepat Guna. Kanisius. Yogyakarta. Hal 24-25.

Kumalaningsih, S dan N. Hidayat. 1995. Mikrobiologi Hasil Pertanian. IKIP. Malang.

Kurniawan, R. 2008. Pengaruh Konsentrasi Larutan Garam dan Waktu Fermentasi terhadap Kualitas Kecap Ikan Lele, Teknik Kimia 2(2):127-125.

Kuswara. 1992. Teknologi Pengolahan Kedelai. Pustaka Sinar Harapan, Jakarta.

Manurung, R. 2016. Daya Terima Cookies Substitusi Tepung Ampas Tahu dengan Tepung Beras Merah dan Nilai Gizinya. Universitas Sumatera Utara, Medan.

Nugraheni, M. 2008. Pembuatan Teknologi Pemanfaatan Limbah Padat Industri Tahu untuk Kecap Ampas Tahu. Inotek, Volume 12, Nomor 1.

Oktavia, N.A. 2012. Studi Pembuatan Tepung Formula Tempe. Skripsi. Universitas Hasanuddin, Makassar.

Rahman, A. 2011. Pengaruh Waktu Perendaman dan Lama Pemasakan Pada Pembuatan Kecap Dari Ampas tahu. Fakultas pertanian Unsyiah, Banda Aceh.

Rochima, E. 2005. Pengaruh Fermentasi Garam terhadap Karakteristik Jambal Roti. Buletin Teknologi Hasil Pertanian Vol.8 No.2 Hal.46-56.

Santoso, H. B. 1993. Pembuatan Tempe Dan Tahu Kedelai Bahan Makanan Bergizi Tinggi. Penebar Kanisius, Yogyakarta.

Silvia, 2011. Pengaruh Penambahan Tepung Tempe Terhadap Mutu Kecap Air Kelapa. Balai Riset dan Standardisasi Industri Padang.

Sukaton, U. 1994. Pemanfaatan Tempe Kedelai dan Bekatul Untuk Pembuatan Kecap. (Kajian dari Lama Penundaan Tempe dan Konsentrasi Larutan Garam terhadap Mutu Kecap. Skripsi. Teknologi Hasil Pertanian. Universitas Brawijaya Malang.

Sulistiani, 2004. Pemanfaatan Ampas Tahu dalam Pembuatan Tepung Tinggi serat dan protein Sebagai Alternatif Bahan Baku Pangan Fungsional. Skripsi, Jurusan Gizi Masyarakat dan Sumber daya Keluarga. IPB. Bogor.

Suprapti, M.L. 2005. Kecap Air Kelapa. Kanisius, Yogyakarta. 